\title{
American Policy towards Minorities in the Arab World: A Case Study
}

\author{
Abdelsalam Njadat, $\mathrm{PhD}$ \\ Management Associate Professor - International Relations \\ AL- Balqaa Applied University \\ Email: drnajadat@yahoo.com
}

\author{
Ahmad Aref AL- Kafarneh, PhD \\ Associate Professor, International Relation \\ AL- Balqaa Applied University
}

Received: April 14, 2016 Accepted: April 28, 2016 Published: May 13, 2016

doi:10.5296/jpag.v6i2.9371 URL: http://dx.doi.org/10.5296/jpag.v6i2.9371

\begin{abstract}
Minorities subject is one of the ignored subjects in the Arab world and is surrounded with a great deal of conservation accompanied with clear efforts to minimize or spell any existing type of this problem where states in the Arab world are still based on tribal and regional basis, which resulted in the interest and care in minorities subject and the foreign intervention and the immersion of most minorities in resistance movements against margination and annulation with the aim of being recognized as partners in the country.

Minorities in the Arab world can be divided into the following types;

(1) Non Arabic linguistics Minorities: Groups that don't use Arabic language as mother language in their daily transactions such as leurds, Armans, Arams, Serian, Turkmans, Shakas, Jews, Nigro, Nobions and Baraberian Tribes.

(2) Non Muslim religion Minorities: Consisting of Christians Jews and other religion groups such as yazeedis, paganism, to taling for (20) million persons.

(3) Non sounnitti Islamic groups; imami shiat (lthnay A shriah), Zaydis, ismailis, Durs, Alawyeen, and Abathyah khawarej.

(4) Non Arabic and Non Muslim Minorities: those minorities that differ from Arab world habitants in terms of language, religion, and descent such as Migros and paganism
\end{abstract}


minorities in the south of Sudan.

Minorities represent one of the most important problems threatening state's national and regional unit, which opens the door for foreign intervention in the state national affairs, politically, economically, or military which will result in threatening internal stability.

Given that united nations in it, current shape represent power relations distribution in the modern global order (system), these powers might Kurds those declaration issued by UN calling for the respect of human and minority rights to intervene in those countries internal affairs under various names such as humanistic intervention given the political and international usage towards human rights issues to control resistant or outlaw countries and the titles of human rights.

The united states as a unipolar, started recently, adopting minorities and human rights issues as part of political requirements, that determine its foreign policy towards this countries or that, according to the way it deals with its minorities. But the proven thing is that the American intervention in minorities affairs has political objectives including its countries policies to be in accordance with American political requirements, and this intervention takes many various linds including military intervention in those countries in which USA has supreme interests and once these interests are secured, withdraw and left those minorities alone.

Keywords: Minorities, Meddled east, Kurds issue

\section{Introduction}

This study is about the American foreign policy towards minorities in the Arab word, in general, and Kurds issue, in particular, where it highlights factors affecting American policy towards Arab's region and Kurds position in this region as well as factors affecting Kurds behavior and its effect on their transaction with United States.

\subsection{Significance of the Study}

The study Significance lies in its attempt to identify Kurds role in carrying out American political plans in Iraq and Syria in particular and the place of curds in the American strategy towards Arab region in general.

\subsection{Hypotheses of the Study}

The study hypotheses is based on that the strategic vision toward Syrian - Iraq Kurds in particular, till 1990s, was aimed at changing policies of governing regimes in these two countries, directly or indirectly through a regional party, while American political behavior has changed since 1990s to exploit Kurds in achieving goals among which changed Iraqi regime and occupying that country. 


\section{Study Questions}

The main research question of this study is about the nature of American vision towards minorities in general and Kurds in particular and this main question leads to other research question of which;

(1) What are the American interests in the Arab region?

(2) What factors affecting Kurds behavior in Syria and Iraq?

(3) What is the Kurds political, economic and social situations? And did they affect the nature of interaction between Kurds and USA?

\section{Research Methodology}

Case study of Iraqi and Syrian Kurds, will be employed in this study, as a model for understanding the way in which USA deals with Kurds to achieve American interests. The study also used the historical approach in analyzing the nature of variables affecting American policy toward Kurds in various historical periods.

\subsection{Significance previous study}

(1) Al - Amari (2000) study entitled "Kurds and strategies for building a country in Iraq after occupation" the study showed that state building features in Kurdstan region was for two aims one staying inside Iraq which means deploying the central country from its content and the other is political and threatening by separating from Iraq in the future.

(2) Jwad (2000) study entitled "the future of Kurds issue in the middle east ". The purpose of this study was to raise the interest of Arab - Islamic world with the necessity to common cooperation to treat this issue as an internal one and to refrain foreign hands in manipulating Kurds issues.

The study also draws the features of the possible solution as well as talking about Kurds in all the Middle East regions.

(3) Ali (2001) study "Kurds issue in Iraq from exhaustion to geopolitical threatening. This study talked about regional and international powers influence in Kurds issue and these powers efforts to let Iraq suffering and bleeding as well as threatening" its political and geopolitical unity.

(4) Brock and Sperl ( ) study the Kurds, propary, A Couteem propary overview, the study talked about Kurds through 25 years of torturing suffering, destruction, hilling and mergering by force. Authors concluded that Kurds nation lives and suffers a critical situation. 


\section{Macrothink

\section{American Policy towards Middle East Issues:}

\subsection{Determinants of American foreign policy towards Arab world}

American interests are the major determinant of its foreign policy towards Arab world, and the united stated never intervene in the international affairs but in what is required to safeguard its commercial and population interests. Meanwhile other superpowers role in the Arab world become minimal as a result of the appearance of United States as a superpower be sides the previous soviet union, so USA worked on fulfilling the space of the region with what serves its and its allies strategic interests including the following:

(1) Securing petroleum supplies with reasonable prices.

(2) Protecting Israel security and superiority.

(3) Fighting Arab unitary orientations.

(4) Facing the previous Soviet Union power.

(5) Preventing any other power from competing for controlling the Arab world. The above interest, from competing for, represent an interrelated and interconnected circle that cannot be separated, but US gave petroleum and Israel security the highest importance in its interests as "strategic interests".

Arab union, as seen by us politicians, is not important in threatening its interests in the Middle East region, therefore America resorted, on a continuous basis, to arouse Arab internal conflicts to keep Arab states for from their critical issues, especially central countries in the Arabic regional system by exploiting internal inconsistencies as minorities and frontiers...

However, with the soviet union collapse and the end of cold war, Israel remains on the top of American interests priorities in the region as it is considered an important support of Arab golf security in the face of Iranian and Iraqi threatening as well as in the face of extreme Islamic movements in the region ${ }^{(1)}$. Till it was time for the united states to occupy in an attempt to enhance Israeli importance in support America militarily ${ }^{(2)}$.

Its probable that the danger of American - Israeli relationship on the Arab world would appear - in the current study, in the light of Israeli diving perspective of the Arab world on minorities basis, where political and ideological elites in Israel call the relationship with minorities "preferies allies"(3).

(1) Mohammad Assaeid Saleem. A interests with united states of America, in Hala Saudi (eds) Arab world and united states, Cairo, Arabic institute for research and studies, 1996, p. 120.

(2) waleed abdelhay. One year on Iraq occupation, ???

(3) Waleed Abdelhay. Barriers of common Arab work, Beirut, Arab union studies centre, 1989, pp. $89-92$. 
(1) Minorities location (position) in the American foreign policy united states has a special view towards minorities in the Arab world, as well as an important position in how to achieve its interests. Upon which its political position is determined. This kind of view was crystalized by several thinking symbols research centers, and institutions allied with American foreign ministry, CIA ministry of defense, and the congress in studying region's minorities their position and role in formulating American policy shape.

Brejenski, for example, regard Arab world minorities as dividing agent in serving Israel for rationalizing its legal existence.. "There will be a middle east consisting of ethnic paganism groups on the basis of state - nation, that will transform into racial and ethnic groups under a regional frame (confederate) and this will allow the Israeli canton to live in the region after cancelling the nationalism idea ${ }^{(4) " .}$

Frank wolf and three of American congressmen introduced, in may, 21, 1997, a law proposal to the congress entitled "Freedom from religious terrany which was intended to establish an office to watch religious abuses and working on sanctioning countries and states involved in such actions, given that suggested sanctions countries to coudenemeet countries, and the American president shall give clear instructions to his agents in the international bank and international Monetary fund to vote against any of the states mentioned in the project. However this law derived its significance in the light of extreme view towards islam and its symbols, and Samuel Hentigton candidated islam as a whole, as considered a source of threat to America and the west, and therefore extremist view of Islam might be used as a source and rationale to act as a protector of religioun minorities, specially that futuristic studies in the united states regards minorities conflicts in the middle east as threat to American interests and nurturing terrorism, and that the solution is to get rid of religious and sect regimes. Kurd outcome will remain a conflict element between region's states if not treated, and that Arab states are the most vulnerable for decay, after the issuance and knowledge of the right of destine determination, and that the most important minorities in the Arab world are Kurds who to not achieve independent state ${ }^{(5) "}$.

CIA report, on the other hand, which addressed the world future from 200-2015, predicted the occurrence of conflicts between nationalities and ethnic groups in the region in terms of extremism and demanding the separation of gouth of Sudan and the occurrence of sectal crisis between kibts and muslims in Egypt, while Kurds will seek to establish a state given the growth of independent trend among Turkish, Syria and Iraqi Kurds ${ }^{(6)}$. Also Iraqi Kurdistan is under civil administration authority by the united nations for transformation period to declare a state like Kosovo region.

(4) Awni, Farsach decay scheme, Cairo, dar Al- mustakbal, al- arabi, 1985, p. 63.

(5) see salah badereldin, Kurds and the united states, democratic and kutdstan party electronic website.

(6) Salah badereldin, opp. Cit. 
And finally the report call for reshaping the middle east with new basics by adding interests, nationalities, and sects such as Kurds people who was a victim of British and French arrangements in the beginnings of the twenty century ${ }^{(7)}$.

Therefore, and based on the above, political, social and economic reform as the first step in treating barriers facing American international new direction about large middle east that stem from an assumption stating that cognitive, political and economic delay stands behind America and west hateness and nurture terrorism sources, so it is imperative to force democracy and reform on Arabic Islamic regimes including USA allies ${ }^{(8)}$.

\subsection{American foreign policy toward Kurds (Iraq)}

American policy, since its interest in Kurds issue, was not balanced, but this interest took a variable shape according to American interests and the extent to which Iraqi and Syrian governments are in accordance or opposite on with their relationships with America. However, it was seen that when their was American Iraqi agreement regarding regional and international issues, America tends to leave Kurds alone, and vice versa, where American support and assistance for Kurds took several types, direct or indirect one. It was noticed, mostly, that American intervention was based on several various internal and external interactions that are, mutually, affecting each other, in other words, intervention in Iraqi Kurds was, more or less, dependent on the internal interactions in terms of factors affecting Kurds behavior and the nature of the relationships with Iraqi governments.

\subsection{Internal and external factors constraining American foreign policy towards Kurds issues}

\section{A- Internal factors:}

Factors that made Kurds issue a source for American intervention in international affairs and this required first identifying factors affecting Kurds behavior.

1. Factors affecting minorities behavior.

Minority can be defined as a group living with other group or groups in the same society or state, but it differs from other groups in terms of language, religious, doctorines or ethnicity or in all these; and the same time, minorities feel these differences and try to maintain its cultural identity, and for that reason minorities face discriminate treatment by excluding it from equal with other groups, either an the cultural, political, economic or social level or on all there levels together. However, number of minority people was not considered in this definition, because its possible that a small group of individual might exit, that dominate all the political system outputs, while a group with large number of persons face a discriminative treatment from the small group.

Therefore our analysis depends on limited number of individuals group subject that dominate

(7) Ibid.

(8) Idrees, Al kanbouri. After Iraq invasion project, Islam Today electronic website, 24/04/2003. 
power by strategic minority, which is the group that combine the small number and political efficiency, However, this state of affair exist for minority in light of certain conditions such as a high degree of homogeneity and a high level of self awareness as organization, possibilities, supplies, and resources as well as living in the same geographical location, accompanied by receiving external support which enable that group to play an important role that exceeds its size, specially when the large group lacks one or more of these qualifications ${ }^{(9)}$. So, some factors affecting minorities behavior can be determined ${ }^{(10)}$.

First, different from dominant group by one or more minority's qualifications as language, religions, doctorine ethnicity or in all these qualifications together, as well as the extent of to which the minority is aware of that difference.

Second: political, economic and situations of the minority.

Third, Minority geographical concentration, that is being concentration in a certain geographical location particularly on the boundaries of the state and the possibility for that minority to spread into the neighboring countries, provided the availability of fortunes and primang resources at the place of concentration.

Fourth, possible external support to that minority.

When tenfortunes and resorsoursce are available with external support, the minority always resort to require ${ }^{(11)}$ the reunification of minorities and regions that are dispersed in more than on country, or requiring (demanding) self - government by achieving a state of cultural, political and economic independency, but not external and defense policies, which means that a country might agree and allocate part of its territory for a special legislation in self government subject.

1- Factor affecting Kurds behavior.

When applied to Iraqi Kurds, factors that affected Kurds behaviors and the mature of their interactions with Iraqi state and foreign powers, can be specified.

A- Kurds cultural qualifications

If the majority of Iraqi - Syrian Kurds believed in the sonnet Islam, while small numbers are sheeitti, and less number are yazeeds, but Kurds differ from Iraqi Arabs in terms of their language, where language of any group is a major qualification of its identity because the

(9) sami, Al-Quraan, minorities in the Arab world and their effects an union, unpublished master thesis, Cairo, Arabic research and stdies institute, 2000, pp. 11- 13.

(10) mrabet, rabeh. The effect of ethnic group an the states stability, Nigerian case study, unpublished master thesis, Algerie university, 1990, pp. 20 -25.

(11) Ibid, pp. 25 -27. This was also proved by an other study, see Waleed Abdlhay. The role of political position of minorities in the success of decentralization, Arabic journal of political scinces, issues, 3, 4, 1989, pp. $101-111$. 
individual person or group has the insict to maintain his heritage and self identity which is a reason for the rising of differences between the state and minority ${ }^{(12)}$.

In addition, Kurds political organization formal one of maintaining self identity determinants. There are also several external variable that had an effect in Kurds and other world minorities attempts in maintaining their cultural identities. However, developments that took place an the international level, specially during the 1980s and what followed, have contributed in minorities maintenance of their cultural identity.

B- Kurds geographical concentration:

The majority of Iraqi Kurds live in the north of Iraq where they constitute (20\%) of Iraqi population $^{(13)}$. And being in the north has a special importance either for the richness of that region with petroleum or minerals (Karkuk and AL- Mosel), or from security aspect that is related to iran - turkey frontier ${ }^{(14)}$, that means that this critical positical of Iraqi Kurdistan and its wealth encouraged demands for separation, mean while wealth and geographical neighborhood with turkey with (10-12) millions of Kurds, Iran, with (5 - 6) millions of Kurds, and Syrian (1) millions of Kurds ${ }^{(15)}$, and the existence of Kurds in this region, formed a motive for Kurds in these countries for independent state for all Kurds.

C- Kurds foreign support:

Foreign support for Iraqi Kurds formed one of the major determinant affecting their behavior, mean while Kurds formed one of the most important conflict management in tools, between Iraq from one part and Iran, Turkey, Israel and USA from the other.

-3-B- external factors: is American mechanism in dealing with Kurds issue, where America always resort to use one political, economic, or military tools to execute its foreign policy towards a country.

\section{American - Kurds Relationships}

\subsection{American policy toward Kurds till Iraqi occupation of Kuwait, 1990}

It is worthy noting that with end of the world war, Kurds, as other minorities, received a promise according to severs agreement that allw them self - independence in Kurdistan, with even a promise of independence if they wish, but this agreement was annulled by Luzon (1923) agreement, by which Kurdistan was divided between Iraq, Iran, Syrian, and the soviet union, provided, the withdrawal of troop, within 6 months after the war. However, with the rise of ba'ath to authority in (1968), American direct intervention in Iraqi affairs started, and

(12) Mrabet, Rabeh. The effect of ethnic group. Opp. Cit. p. 20.

(13) for more accurate numbers, see Jalal Moawad. Kurds \& Turkmen, opp. Cit. pp. 4-5.

(14) Ibid, p. 12, 17.

(15) Assayed Al-Marakby integraity in Iraq Nationality in cuse study 1988-1996 Bagdad Future Center strategy . Second golf war, opp. eit, p. 48. 
Iraqi Kurds because one of its tools and the previous development form the main motive for American intervention in Iraqi affairs using Kurds for the purpose of: Making Iraq preoccupied with its internal affairs, to secure petroleum supplies, third weakening Iraqi role in the Arab golf region, fourth weakening of Iraq in the face of Iran and Israel (before Islamic revolution, 1979) given they are main allies of American in the region, and fifth to hinder soviet power and control in the Arab golf by aliening with Iraq ${ }^{(16)}$.

From the above it can be seen that American - Iranian coordination to support Iraqi Kurds was aimed at weaking Iraqi regime and finding a state of instability in Iraq to exploit and exhaust Iraqi energies politically and economically ${ }^{(17)}$, taking consideration that this support should not exceed the limit that allows Iraqi Kurds of independence.

It is understood that American and Iran were not liking to give place for Iraqi government to settle Kurds issue, but keeping Iraq in an internal fighting state, and this vision of Kurds future is one of Iranian and American bans because it represents direct threat to Iran. Therefore American support for Kurds was specified as long as Kurds is one part of regional issue to be dealt with according to regional variables and American interests in the region.

This can be supported through American refusal of Israeli demand from Mustafa Barazani to make a large attach in the Iraqi territory when Iraqi troops participated in October (1973) war on the Syrian side.

Soviet union collapse give American the opportunity to form a new world order under an American absolute control known as unipolar world system as well as controlling petroleum springs and managing economic competition towards other international political and economic powers $^{(18)}$.

Iraqi occupation of Kuwait, in (1990), formed, according to American politicians, a threat to its major strategic interest, as follows: it was considered as a step threatening its strategic allie (Israel); second: occupying and coutrolling one of the most important petroleum sources in the region, that is Kuwait, third if Iraq succeeded and joined Kuwait, this meant its control over petroleum markets. Therefore American lead an international alliy to spell Iraq from Kuwait and destroy its military power.

Iraqi invasion of Iraq gave Kurds a great opportunity to benefit from. American policy after that date was aimed at providing Kurds with all kinds of support.

But the way by which Kurds revolution was destroyed raised questions about the purpose of American silence and why American allowed Iraqi army to use Helicopters with no arms

(16)Mohammad Assammak, opp, Minorities between Arabism and Islamic, Bagdad- Dar Alalm .

(17) Mohammad Assammak, opp, cit, pp. $44-45$.

(18) Mohsen Awad. American Arabs relations in 1990s, in hala saudiceds Arab world and united states, Cairo, Arabic research and studies institute, 1996, p. 151. 
according to fire cease negotiations at safwan? And what are the reasons behind that informational and media supply about Kurds suffering while revenging to Iran and Turkey? Was American unable to intervene directly and change the Iraqi regime? Subsequent developments proved that American silence was aimed at creating suitable and justified atmospheres for intervening in the Iraqi affairs later on, and to justify its existence in Iraq for the protection of Kurds, American stared to abort the dialogue held between Kurds and Iraqi leaders (1991), about self governing agreement in Kurdistan, but the American purpose was to deny Iraq keeping its national unity for Kurds issue to remain a paper used by Americans to press both Iraqi system and identity ${ }^{(19)}$.

In these instances we found that American led an international intervention to protect Kurds who were dispersed in front of Iraqi suppression as a result of their rebel, which required providing more than (10) solders to carry rescue opperations for more than (1) million Kurds refugees, followed by taking permanent arrangement under the umbrella of working towards aborting an other of Kurds torturing as well as creating safe conditions with warning Iraq of and abortion or hindering of these efforts according to security council resolution, (688, April, $5,1991)$.

In this context, a safe zone in the north of latitude 32 enjoying American and western protection in an attempt to encourage Kurds refugees to come back to their homes, this was accompanied by the formation of fast intervention force in cooperation with some of the international allie against Iraq, which was positioned in Turkey to be ready to move in the case of the occurrence of a new encounter between Iraqi forces and Kurds to be the starting point to end Iraqi government on Kurds north region ${ }^{(20)}$.

Kurds - Kurds conflict exploded from (1993 - 1996) as a result of fierce economic crisis resulting international sanction on the whole large, in general and Iraqi sanction on Kurdstan, as well as attempts by neighboring countries (Turkey and Iran) to extend their control Iraqi Kurdstan, as well as the rising of new Kurds movements and forces seeking to play a role in Kurds area such as Islamic movement and others ${ }^{(21)}$. America took the silence position towards that conflict, but with what serves its interests as an attempt to make Iraq and Iran go into conflict.

\subsection{Kurds and American occupation of Iraq}

September, 11, actions were a factor often American acceleration of its accusation of Iraq by

(19) Abdelelah, baltazeez. The difficult project: decay in the colonial invasion of Iraq Almustakbal Al- arabi, issue, 291, 2003,p. 53.

(20) Waleed, Abdelemajeed. International political variables in the cementer, opp. cit, pp. $119-120$.

(21) for reason of Kurds internal conflicts see sa'ad addin Ibrahim, (supervisor): border, bees and spicies, fifth annual report, 1998, Cairo, ibn - khldoun center, pp. 176 - 178. And Ahmad Turkey, Kurds issue in Iraq, international policy, 135, p. 120. 
classifying it into evil axis with north Korea and Iran and it started working on two parallel directions to change Sadam Hussein regime and occupying Iraq, as well as assisting Iraqi resistance, the first direction appeared in London conference an November, 2002, of which a committee of coordination and follow - up was formed, which held a conference (meeting) at Salaheddin Earp at Iraqi Kurdistan in the late of February, 2003, where Iraqi resistance leading committee was formed including Masood Barazani and Jalal Talbani from the Kurds. This committee declared its vision in building parliamentary federal system in a united Iraq, and its refusal of any regional intervention in Iraqi affairs, specially Kurdistan, as well as its refusal of any envision or occupation of Iraq ${ }^{(22)}$. The other direction, that parralled the first one, included America taking steps towards preparation for launching a military operation, of which points of launching will be Iraqi - Kurdistan. However, during the last ten years, they were helped by the collapse of Iraqi state identities where subsequent development on Iraqi territory indicated that Iraqi future was under the control of Kurds well under American efforts to inculcate this state within state official institutions.

From the above discussion we can envision the American role in enhancing Kurds influence in the temporary law in a manner that makes Iraqi Kurds an active agent in Iraqi state future, giving them the opportunity to impose their opinions on the Iraqi states.

\subsection{The future of American Kurds relationships (Iraqi)}

The future of these relation will largely depend on the geographical position on the American interests map in region, and an several internal and regional determinant in the second place. till now, one of the American occupation is establishing a weak Iraqi state serving its interests in the region, while, preventing the development of a strong central state in the vicinity of petroleum wells and Israel ${ }^{(23)}$.

These perceptions and visions of type and nature of these new relationships was determined by rand foundation, an affiliate of the American National defence research institute 1993, by stating all choices in the Iraqi front assume a state with fragile structure and diminished ability to practice power in the region compared to the situation during the last decades and Iraqi will never became a state enjoying stability unless by creating some type of democratic representative goremace, and this night demand shifting towards federation and Iraqi $\operatorname{Kurdistan}^{(24)}$.

These final directions towards Kurds and their future are enhanced with what we see of American closing eyes about non intimate practices by Beshmerga forces toward Karkuk and Mosel habitants which aimed, also, at creating a state of constant and continuous tenion

(22)Derrisah, Away, Kurds problem, , opp. cit. p. 50.

(23)Abelelah, Belfreez, The resistant (difficult) project opp. cit. p. 53.

(24)agraham, fold, Iraq in the coming decade, will it beable to survive, Abu Dhabi- Emirates Center for research, pages 8,11 . 
between Kurds and other Iraqi population components ${ }^{(25)}$. Also, its adoption of Kurds in the temporary state Administration law is to make Iraq in a situation of internal conflict, but despite this, it is worth emphasizing, here, that American adoption of Iraqi Kurds will not reach the degree of allowing them to separate from Iraq in the coming future, and this is due to reason specific of Kurds themselves, and to regional conditions and American interest in making Iraqi Kurdistan an endless division project ${ }^{(26)}$ in an attempt to abusing Iraqi national force in the future and regional powers related to American future project in the region.

However, despite that independent dream of Kurds and which was used by Kurds leaders before signing the temporary state administration law if their demands were not fulfilled, this is supported by the fact that Kurds form the largest ethnic group in the middle east that has no state, despite its enjoyment of political maturity due to its previous experience in self government, and the agreement between the two major political Kurdish parties in Iraq Kurdistan, as well as its possession of the largest armed and organized forces, where Kurds started to depart of their visions of Iraqi future and their position within, in a more powerful manner, and this can be supported by the recent movements towards unifying the two Kurds administrations in Arbeel and Assutimanyeh to give Kurds on efficies authority ${ }^{(27)}$.

Even though the above discussion carries power elements for Kurds. Encouraging their separation prospects, the mixture and wavering in these fears have encouraged the forgetness of conflicts between Syria and Turkey and pushing them to coordinate regarding Kurds issue in cooperation with Iran the fourth side of the Kurds square. These fears were proven during the last visit of Syrian president to turkey on January, 2004, and their agreement to coordinate their efforts regarding this issue and emphasizing the importance of Iraqi regional unity ${ }^{(28)}$.

Therefore, we can say that the three neighboring countries of Iraq adopted a unified position in the face of American power when it stand as a threat to their national security, and for the same reason, we find that American with its awareness to the reflection of Kurds issue on the regional powers, will resort to keep its policy toward Kurds as it is in the seen future and using it to arouse regional forces and to adapt its policy in accordance with its interests. Also, and in the same direction, American use the Kurds paper to prorocate regional national forces. In other words, if Turkey stand as a barrier, in the future, in face of American interests as happened during Iraq invasion in 2003, America will resort and threat to use Kurds separation paper, which is the American position towards Syria the weakest country in the region, and the swap will be in a way or another the Syrian position of the peace process with Israel.

This is also true regarding Iran, in terms of American - Iranian conflicts regarding Iran armament programs and the position towards Israel, but the most important factor is its relationships with sheeitti powers in Iraq, knowing that American provocation of Iran through

(25)Abdeleleah, belgzeez, opp. cit. pp. 55-57.

(26)Mohammed A'ddori, The occupied Iraq.. opp. cit.

(27)three events, Al - Bayan News paper, opp. cit.

(28)Risks and division.. Jordanian Al- Arab Al-youm news paper, 15/ 5/2004. 


\section{MInstitute Macrothink $^{m}$}

Kurds issue might be less influential than that on other countries, due to Iranian influence on Iraqi sheeitti, and if American posses Kurds paper, Iran possesses the sheeitti paper with what it means of power sources to Iran.

If this is the researchers analysis about the future of American - Kurds relationship, there are internal and external voices in America calling or adopting the division of Iraq into three states, Kurdish, sonneitti, and sheeitti ${ }^{(29)}$. But despite this Iraqi internal constraints and regional ones, remain the actives factor in determining the future of American Kurdish relationships. This study contributes to understand American policy regarding minorities the Arab world in testing results reached by the researchers regarding American political position towards Iraqi Kurds. And for this particularity presented several debate for the situation under detailed study: habitants of south Sudan in Sudan, Barbarians in Al- qerie. Mawarneh in Lebanon and researchers took these cases because they are the most minorities intervention by America in thein affairs and the most provocative of problems, and because they represent cases in central states within Arab regional system (Sudan, Egypt, Al-gerie) and Lebanon given that American intervention took an ever incread for than that in other Arab countries.

\section{Conclusion}

States in the western world succeeded in transforming into national state that melted sects and ethnic groups inside it, but Arab countries did not have this opportunity, so it conserves its mosaic style through its dependence (relying) on tribal and denomination and regionality after its independence and the forming of the national state therefore it is natural that these minorities feel the degree of marginalization and annulations, for that Kurds have long sought to self governance but these demands was always based on the nature of regional and global variables, where they always victims of these variables.

its hopped that the objective conditions that surrounded Kurds made them an instrument through which external forces penetrate these countries, as is the case with America which sought to exploit Kurds to change government systems in Iraq, and make condition in favor of exploiting them in changing Iraqi regime and occupying it, while emphasizing that American interest in Iraqi Kurds in particular, was not for Kurds interest only, but as a tool to protect and maintain American interest in the region. Comparison of American behavior towards other minorities with that for Kurds, revealed that American intervention was aimed at pressing governing regimes (systems to change their policies towards issues related directly to American interests.

\section{Reference}

Abdelelah, Baltazeez. The Difficult Project: Decay In The Colonial Invasion Of Iraq AlMustakbal Al- Arabi, Issue, 291, 2003,P. 53.

Abelelah, Belfreez, The Resistant (Difficult) Project Opp. Cit. P. 53. 
Agraham, Fold, Iraq In The Coming Decade, Will It Beable To Survive, Abu DhabiEmirates Center For Research, Pages 8,11.

Ali, Mousa Al-Said(2001) Kurds Issue At Iraq From Draining To The Geographic Threat, Abu Dhabi- Emirate Center For Research And Strategy.

Al-Omari, Ibtisam Mohammad(2001), The Kurds And State Building Strategy In Iraq After The Occupation, Bagdad, Nationality And Strati Ages Research Center, Bagdad University.

Assayed Al-Marakby Integraity In Iraq Nationality In Cuse Study 1988-1996 Bagdad Future Center Strategy . Second Golf War, Opp. Eit, P. 48.

Awni, Farsach Decay Scheme, Cairo, Dar Al- Mustakbal, Al- Arabi, 1985, P. 63.

Derrisah, Away, Kurds Problem, , Opp. Cit. P. 50.

For More Accurate Numbers, See Jalal Moawad. Kurds \& Turkmen, Opp. Cit. Pp. 4-5.

For Reason Of Kurds Internal Conflicts See Sa'ad Addin Ibrahim, (Supervisor): Border, Bees And Spicies, Fifth Annual Report, 1998, Cairo, Ibn - Khldoun Center, Pp. 176 - 178. And Ahmad Turkey, Kurds Issue In Iraq, International Policy, 135, P. 120.

Ibid, Pp. 25 -27. This Was Also Proved By An Other Study, See Waleed Abdlhay. The Role Of Political Position Of Minorities In The Success Of Decentralization, Arabic Journal Of Political Scinces, Issues, 3, 4, 1989, Pp. $101-111$.

Idrees, Al Kanbouri. After Iraq Invasion Project, Islam Today Electronic Website, 24/04/2003.

Jwad, Sa'ad Nagi(2000) Kurds Issue Future In The Middle East Bagdad Middle East Center Research Series Report.

Mohammad Assaeid Saleem. A Interests With United States Of America, In Hala Saudi (Eds) Arab World And United States, Cairo, Arabic Institute For Research And Studies, 1996, P. 120.

Mohammad Assammak, Opp, Cit, Pp. $44-45$.

Mohammad Assammak, Opp, Minorities Between Arabism And Islamic, Bagdad- Dar Alalm .

Mohammed A'ddori, The Occupied Iraq.. Opp. Cit.

Mohsen Awad. American Arabs Relations In 1990s, In Hala Saudiceds Arab World And United States, Cairo, Arabic Research And Studies Institute, 1996, P. 151.

Mrabet, Rabeh. The Effect Of Ethnic Group An The States Stability, Nigerian Case Study, Unpublished Master Thesis, Algerie University, 1990, Pp. 20 -25.

Philp , G Kreyenbrock And Stefan Sperl (2000)The Kurda, A Contemporary Overview Rutledge/ Soas Politics And Center In The Middle East London. 


\section{Macrothink}

Risks and division.. Jordanian Al- Arab Al-youm news paper, 15/ 5/2004.

Sa'edeldin, Ibrahim, AL-Milal Walnahal Walarag Minorities Concerns In The Arab World, Cairo, Ibn Khaldun Centre, 1994, Pp, 740 - 749.

Sami, Al-Quraan, Minorities In The Arab World And Their Effects An Union, Unpublished Master Thesis, Cairo, Arabic Research And Stdies Institute, 2000, Pp. 11- 13.

See Salah Badereldin, Kurds And The United States, Democratic And Kutdstan Party Electronic Website.

Three Events, Al - Bayan News Paper, Opp. Cit.

Waleed Abdelhay. Barriers Of Common Arab Work, Beirut, Arab Union Studies Centre, 1989, Pp. $89-92$.

Waleed, Abdelemajeed. International Political Variables In The Cementer, Opp. Cit, Pp. 119 -120$.

\section{Copyright Disclaimer}

Copyright for this article is retained by the author(s), with first publication rights granted to the journal.

This is an open-access article distributed under the terms and conditions of the Creative Commons Attribution license (http://creativecommons.org/licenses/by/3.0/). 